\title{
Pengaruh Latihan Range Of Motion terhadap Peningkatan Kemampuan Melakukan Activity Daily Living pada Penderita Pasca Stroke
}

\author{
Vier Nofrel \\ Universitas Padjadjaran \\ Correspondence email: viervier@yahoo.co.id
}

\begin{abstract}
Abstrak. Stroke menjadi masalah serius yang dihadapi hampir diseluruh dunia. Insiden stroke bervariasi antar negara dan tempat. Stroke menduduki urutan ketiga terbesar dinegara maju dan sebagai penyebab kematian ketiga setelah penyakit jantung dan kanker. Angka kecacatan akibat stroke umumnya lebih tinggi dari pada angka kematian, secara global 15 juta orang terserang stroke setiap tahunnya, satu pertiga meninggal dan sisanya mengalami kecacatan permanen. Pemulihan fungsi motorik sebagai pendukung pergerakan tubuh pada klien pasca stroke adalah hal yang sangat penting. Hal ini karena lebih dari $85 \%$ klien yang menderita stroke mengalami disfungsi ekstremitas atas. Study Literatur ini bertujuan untuk menganalisis efektifitas latihan Range of Motion (ROM) terhadap peningkatan kemampuan gerak atau kemandirian Activity Daily Living (ADL) pada klien pasca stroke. Penelitian ini menggunakan metode kajian literatur dengan menganalisi hasil-hasil penelitian sebelumnya. Pencarian artikel dilakukan pada tanggal 19 Agustus sampai 31 Agustus 2019 melalui database Pro-quest, Pubmed dan Science Direct dengan menggunakan kata kunci Activity Daily Living AND Range of Motion AND Post Stroke, kemudian pemilihan artikel berdasarkan kriterria inklusi dilakukan critical appraisal sehingga artikel yang relevan berjumlah 14 artikel. Dari beberapa penelitian yang telah dilakukan oleh peneliti terdahulu didapatkan hasil bahwa ada pengaruh yang signifikan dari latihan Range of Motion terhadap peningkatan kemampuan rentang gerak klien stroke. Program latihan Range of Motion efektif dalam meningkatkan kemampuan rentang gerak klien pasca stroke sehingga akan berdampak pada peningkatan kemampuan klien dalam melakukan activity daily living.
\end{abstract}

Kata Kunci: Activity Daily Living; Range of Motion; Post Stroke

Abstract. Stroke is a serious problem faced almost all over the world. The incidence of stroke varies between countries and places. Stroke ranks third largest in developed countries and is the third leading cause of death after heart disease and cancer. The disability due to stroke is generally higher than the mortality rate, globally 15 million people have a stroke each year, one third die and the rest experience permanent disability. Restoration of motor functions as a supporter of body movements in poststroke clients is very important. This is because more than $85 \%$ of clients who suffer stroke have upper limb dysfunction. This Literature Study aims to analyze the effectiveness of Range of Motion (ROM) exercises on improving the ability of motion or independence of Activity Daily Living (ADL) in post-stroke clients. This study uses the literature review method by analyzing the results of previous studies. Search for articles was conducted on August 19 to August 31, 2019 through Pro-quest, Pubmed and Science Direct databases using the keywords Activity Daily Living AND Range of Motion AND Post Stroke, then article selection based on criterion of inclusion was carried out critical appraisal so that the relevant articles amounted 14 articles. From a number of studies conducted by previous researchers, it was found that there was a significant effect of Range of Motion training on increasing the ability of the stroke client's range of motion. The Range of Motion training program is effective in increasing the ability of the client's range of motion after a stroke so that it will have an impact on increasing the ability of clients to do daily living activities.

Keywords : Activity Daily Living; Range of Motion; Post Stroke

\section{PENDAHULUAN}

Dewasa ini stroke semakin menjadi masalah serius yang dihadapi hampir diseluruh dunia. Insiden stroke bervariasi antar negara dan tempat. Stroke menduduki urutan ketiga terbesar dinegara maju dan sebagai penyebab kematian ketiga setelah penyakit jantung dan kanker, dengan laju mortalitas $18 \%$ sampai $37 \%$ untuk stroke pertama dan $62 \%$ untuk stroke berulang (Bustan, 2007). Menurut WHO (World Health Organization) tahun 2012, kematian akibat stroke sebesar 51\% di seluruh dunia berawal dari tekanan darah tinggi. Badan kesehatan dunia memprediksi bahwa kematian akibat stroke akan meningkat seiring dengan kematian akibat penyakit jantung dan kanker. Data WHO (2010) menyebutkan setiap tahunnya terdapat 15 juta orang diseluruh dunia menderita stroke dimana 6 juta orang mengalami kematian dan 6 juta orang mengalami kecacatan permanen dan angka kematian tersebut akan terus meningkat dari 6 juta ditahun 2010 menjadi 8 juta ditahun 2030.

Kematian akibat stroke sebesar $51 \%$ di seluruh dunia berawal dari tekanan darah tinggi. Dalam 2 terbitan Journal of the American Heart (JAHA) 2016 menyatakan terjadi peningkatan kasus pada individu yang berusia 25 sampai 44 tahun menjadi (43,8\%) (JAHA, 2016). Meningkatnya jumlah penderita stroke diseluruh dunia juga meningkatkan penderita stroke yang berusia dibawah 45 tahun. Pada konferensi ahli saraf international di Inggris dilaporkan bahwa terdapat 
Vier Nofrel, Pengaruh Latihan Range Of Motion terhadap Peningkatan Kemampuan Melakukan Activity Daily Living pada Penderita Pasca Stroke

lebih dari 1000 penderita stroke yang berusia kurang dari 30 tahun (American Heart Association, 2010).

Hasil Riset Kesehatan Dasar (Riskesdas) Nasional tahun 2018 menyatakan prevalensi stroke di Indonesia berdasarkan diagnosis tenaga kesehatan pada penduduk usia $\geq 15$ tahun sebesar 10,9 per mil, meningkat dibandingkan dengan tahun 2013 sebesar 7 per mil. Pada tahun 2010 stroke menempati posisi kedua penyakit terbanyak (kasus baru) sedangkan pada tahun 2011 stroke menempati posisi pertama penyakit terbanyak (kasus baru) dengan jumlah kasus sebanyak 228 kasus. Stroke merupakan penyebab kematian nomor 1 di Indonesia (CDC, 2013).

Berdasarkan data yang berhasil dikumpulkan oleh Yayasan Stroke Indonesia (Yastroki), stroke di Indonesia terbanyak dan menduduki urutan pertama di Asia. Jumlah kematian yang disebabkan oleh stroke menduduki urutan kedua pada usia diatas 60 tahun dan urutan kelima pada usia 15-59 tahun (Yastroki, 2012). Di Indonesia diperkirakan setiap tahun terjadi 500.000 penduduk terkena serangan stroke, sekitar $2,5 \%$ atau 125.000 orang meninggal, dan sisanya mengalami cacat ringan maupun berat. Secara umum dapat dikatakan angka kejadian stroke adalah 200 per 100.000 penduduk.

Stroke menurut AHA/ASA (American Heart Association/American Stroke Association) tahun 2017 adalah disfungsi neurologis yang disebabkan oleh infark fokal serebral, spinal maupun retina, dimana infark pada susunan saraf pusat mempunyai definisi infark serebri, medula spinalis atau retina yang terkait kematian sel karena iskemia. Sedangkan National Institute of Neurological Disorder and Stroke menyatakan bahwa stroke terjadi ketika pasokan darah ke bagian otak dengan tiba-tiba terganggu atau ketika pembuluh darah di otak pecah dan berakibat penumpahan darah ke dalam ruang yang mengelilingi sel-sel otak. Sel-sel otak mati ketika sudah tidak menerima oksigen dan nutrisi dari darah dalam waktu yang lama atau secara tiba-tiba terjadi perdarahan kedalam atau sekitar otak (NINDS, 2015). Stroke adalah manifestasi klinis dari gangguan fungsi otak, baik fokal maupun global (menyeluruh), yang berlangsung cepat, berlangsung lebih dari 24 jam atau sampai menyebabkan kematian, tanpa penyebab lain selain gangguan vaskuler (WHO, 2010).

Angka kecacatan akibat stroke umumnya lebih tinggi dari pada angka kematian, secara global 15 juta orang terserang stroke setiap tahunnya, satu pertiga meninggal dan sisanya mengalami kecacatan permanen (Stroke forum, 2015). Menurut American Heart Association (2014), stroke merupakan penyebab utama kecacatan yang dapat dicegah. Pada pasien stroke, 70$80 \%$ mengalami hemiparesis (kelemahan otot pada salah satu sisi bagian tubuh) dengan $20 \%$ dapat mengalami peningkatan fungsi motorik dan sekitar 50\% mengalami gejala sisa berupa gangguan fungsi motorik/kelemahan otot pada anggota ekstrimitas bila tidak mendapatkan pilihan terapi yang baik dalam intervensi keperawatan maupun rehabilitasi pasca stroke (Akner, 2005). data Perhimpunan Rumah Sakit Indonesia (PERSI) menunjukkan bahwa tingkat kecacatan mencapai 65\% (DepKes, 2013). Sedangkan hasil Riskesdas (tahun 2013) yaitu dari keseluruhan klien yang datang rawat jalan kerumah sakit sebanyak 55-60\% orang dengan gejala stroke menderita cacat ringan sampai berat.

Range of Motion (ROM) merupakan bentuk latihan dalam proses rehabilitasi pada pasien dengan stroke yang meliputi sejumlah pergerakan yang mungkin dilakukan oleh bagian-bagian tubuh. Tujuan rehabilitasi antara lain: mencegah komplikasi penyakit, meningkatkan kemampuan ADL pasien, meningkatkan harga diri dan mekanisme koping pasien. Semakin dini proses rehabilitasi dimulai maka kemungkinan pasien mengalami defisit kemampuan akan semakin kecil (Soeparman,2004). Latihan ROM dapat diklasifikasikan menjadi dua yaitu latihan ROM Pasif dan Latihan ROM Aktif. Latihan ROM pasif adalah latihan ROM yang di lakukan pasien dengan bantuan perawat/keluarga pada setiap-setiap gerakan. Latihan ROM aktif adalah Perawat memberikan motivasi, dan membimbing klien dalam melaksanakan pergerakan sendi secara mandiri sesuai dengan rentang gerak sendi normal.

Lewis (2007) mengemukakan bahwa sebaiknya latihan pada penderita stroke dilakukan beberapa kali dalam sehari untuk mencegah komplikasi, semakin dini proses rehabilitasi di mulai, maka kemungkinan penderita mengalami defisit kemampuan akan semakin kecil. Latihan ROM dapat meningkatkan fleksibilitas dan rentang gerak sendi. Kekuatan otot pada penderita stroke dapat segera dipulihkan melalui latihan ROM setelah serangan stroke berlalu. Dampak latihan ROM yang tidak segera dilakukan pada pasien stroke sedini mungkin adalah terjadinya atropi sel otot, kekakuan sendi, penurunan kontraksi otot, nyeri saat pergerakan dan secara keseluruhan akan berakibat pada ketidakmampuan untuk bergerak atau beraktifitas.

Dengan melihat kejadian stroke diatas serta gejala sisa yang dialami klien, maka dilakukan kajian literature yang mendalam terhadap bagaimana upaya yang dapat dilakukan dalam rangka meningkatkan kapasitas rentang gerak klien guna meningkatkan kemampuan klien dalam melakukan activity daily living.

\section{METODE}

Pencarian artikel dimulai tanggal 19 - 31 Agustus 2019 malalui database Proquest, Pubmed, dan Science Direct dengan menggunakan kata kunci Activity Daily Living and Range of Motion and Stroke. Kemudian pemilihan artikel berdasarkan kriteria inklusi. Setelah melakukan proses pemilihan artikel dengan kriteria inklusi yang berjumlah 221 artikel, kemudian dilakukan critical appraisal. Dari 221 artikel yang dilakukan critical appraisal didapatkan artikel yang relevan untuk dilakukan literature review sebanyak 14 artikel.

Kritaria artikel untuk dilakukan literature review : 
Kriteria Inklusi : Penelitian berkaitan dengan Range of Motion, Penelitian berkaitan dengan pasien Pasca Stroke, Penelitian berkaitan dengan kemampuan Activity Daily Living, Teks lengkap.

Kriteria Eksklusi : Publikasi hanya abstrak saja dan editorial
HASIL DAN PEMBAHASAN

Kajian artikel diidentifikasi dari 14 artikel yang sudah dilakukan dengan langkah-langkah kritis sehingga dapat dilihat bahwa dari 14 artikel membahas tentang efektifitas latihan range of motion terhadap kemampuan activity daily living.

\begin{tabular}{|c|c|c|c|}
\hline $\begin{array}{c}\text { (Authors \& } \\
\text { Year) }\end{array}$ & $\begin{array}{c}\text { Sample } \\
\text { (characteristics, size, } \\
\text { settings) }\end{array}$ & Design & Purpose \& Intervention \\
\hline $\begin{array}{l}\text { Author: } \\
\text { Mayo. N. E, et al } \\
\text { Year : } \\
2013\end{array}$ & $\begin{array}{l}\text { Sampel dalam pene- } \\
\text { litian ini berjumlah } 87 \\
\text { orang: } \\
43 \text { klien pasca stroke } \\
\text { yang dirawat dirumah. } \\
44 \text { klien pasca stroke } \\
\text { yang menjalani rawat } \\
\text { jalan dirumah sakit, } \\
\text { dengan kriteria klien } 1 \\
\text { tahun pasca stroke } \\
\text { yang mempunyai ke- } \\
\text { mampuan berjalan } \\
\text { lebih dari } 10 \text { meter }\end{array}$ & $\begin{array}{l}\text { Observer-blinded, } \\
\text { randomized, prag- } \\
\text { matic, trial with } \\
\text { repeated measures. } \\
\text { Penelitian dilakukan } \\
\text { selama } 12 \text { bulan. }\end{array}$ & $\begin{array}{l}\text { Penelitian bertujuan Untuk melihat } \\
\text { efektivitas dalam meningkatkan } \\
\text { kemampuan berjalan dan mobilitas } \\
\text { pada pasien pasca-stroke dengan } \\
\text { dua intervensi setara, yaitu } \\
43 \text { sampel yang dirawat dirumah } \\
\text { diberi latihan dengan sepeda } \\
\text { stasioner selama maksimal } 30 \text { menit } \\
\text { sehari. } \\
44 \text { sampel yang menjalani rawat } \\
\text { jalan dirumah sakit diberi latihan } \\
\text { mobilisasi jalan cepat selama } \\
\text { maksimal } 30 \text { menit perhari. }\end{array}$ \\
\hline
\end{tabular}

Author :

Smallfield. S

DrOT \&

Karges, PT, EdD,

MS

Year :

2009

Author : berjumlah 19 orang.

Year :

2014

9 Klien dengan latihan

10 Klien Latihan ROM

+ combinasi (senam, berenang)

Kriteria inklusi : usia antara 20 dan 65 tahun.

Author :

Sampel berjumlah se-

Bernhardt. J., et al banyak 71 orang, sampel dalam kondis

Year :

2017
Non experimental, retrospektif

Penilaian melalui exercise test cardio pulmonary, tes fungsi paru, pengukuran mobilitas tulang belakang, ekspansi dada, Indeks Barthel, dan kemampuan fungsional lainnya. Penelitian dilakukan selama 3 bulan.

Blinded randomized trial control.
Tujuan dalam penelitian ini adalah untuk mengetahui jenis intervens tertentu yang sering digunakan dalam rehabilitasi. Penelitian in melihat intervensi mana yang sering digunakan, apakah intervens prefunctional (ROM) atau kegiatan yang lebih fungsional seperti latihan ADL.

Penelitian bertujuan membandingkan efektivitas latihan ROM dirumah dan latihan gabungan ROM + latihan lainnya Subyek dalam kelompok ROM diberikan latihan ROM pada tulang belakang dan sendi utama (termasuk bahu, siku, pergelangan tangan, pinggul, lutut, dan pergelangan kaki) dari terapis fisik senior.

Kemudian klien dianjurkan untuk melakukannya sendiri setiap hari selama 3 bulan. Setiap latihan ROM diulang 5 kali.

Kelompok Kombinasi diberikan latihan ROM yang sama dan latihan aerobik (termasuk berjalan cepat, bersepeda, dan berenang).

Program latihan aerobik terdiri dari 5 menit peregangan otot, 5 menit pemanasan, $20-30$ menit latihan aerobik, dan 5 menit pendinginan. Setiap subjek dalam kelompok diminta untuk melakukan latihan aerobik 3 kali per minggu selama 3 bulan.

Tujuan penelitian untuk meliha keamanan pemberian rehabilitas pada 24 jam pertama sampaI 14 hari pertama serangan stroke.

Intervensi yang diberikan adalah

33 klien diberikan perawatan
24 jam pertama serangan stroke dengan skor NIHSS rata-rata
Finding author conclutions

Dari penelitian yang dilakukan selama waktu 12 bulan didapatkan hasil dimana kedua program sama-sama efektif dalam mempertahankan kapasitas berjalan

(rasio odds global (OR) untuk bersepeda vs latihan jalan adalah 0,51; 95\% confidence interval $(\mathrm{CI}), 0,27-0,95)$ adalah signifikan secara statistik $(\mathrm{p}=0,022)$.

Hasil penelitian menunjukkan dari 1554 sesi yang dilakukan, bahwa kegiatan prefunctional (ROM) adalah latihan yang paling sering digunakan untuk rehabilitasi klien stroke yaitu 1.022 sesi $(65,77 \%)$. Kegiatan Prefunctional bertujuan untuk meningkatkan fungsi dan struktur tubuh untuk mempersiapkan klien berpartisipasi dalam aktivitas yang lebih fungsional.
Dari tingkat kepatuhan dalam melakukan latihan, kelompok ROM memiliki tingkat kepatuhan lebih tinggi dalam latihan (54\%) dibanding kelompok kombinasi (48\%).

Dalam perbandingan Rentang gerak dan ekspansi dada, tidak ada perbedaan statistik yang signifikan antara kelompok $(P<0,05)$

Tidak ada perbedaan yang signifikan dalam uji latihan cardiopulmonary antara kedua kelompok. Untuk fungsi paru, tidak ada perbedaan signifikan diantara kedua kelompok.

Untuk perbandingan efek latihan, tidak ada perbedaan statistik yang signifikan dalam setiap kelompok.

Untuk kemampuan fungsional, terjadi peningkatan kemampuan fungsional pada kedua kelompok, namun tidak ada perbedaan statistik yang signifikan antara kedua kelompok setelah latihan 3 bulan $(P=0,028)$

Tidak ada perbedaan yang signifikan dalam jumlah keamanan (kematian) antara kelompok (SC, 3 dari 33 dan VEM, 8 dari 38; $\mathrm{P}=0.20$ ).

Hasil keselamatan sekunder adalah sama antar kelompok.

Keberhasilan intervensi mencapai target dalam 
pada masuk $10 \pm 6.9$ dan stroke iskemik adalah jenis yang paling banyak $(87 \%, \mathrm{n}$ $=62$ ).

Author :

Hamzah. A and Sugiyanto

Year : 2014

Author :

Handayani, S

Year :

2014

Author :

Yudha, F \&

Amatiria, G

Year :

2014

Author :

Murtaqib

Year :

2013

Author :

Sampel dalam peneYear : 2018 litian ini adalah pasien pasca stroke di Kota litian ini berjumlah 31 pasien pasca stroke yang sedang menjalani perawatan pada poliklinik stroke Rumah Sakit Al Islam

Bandung, Indonesia.

Sampel diambil dengan teknik purposive sampling.

kriteria stroke non hemoraghic. Kondis pasien sadar dan tenang, kooperatif.

Sampel dalam penelitian ini adalah lansia yang berumur 60 tahun keatas yang memenuh kriteria inklusi di Kab. Klaten, Jawa Tengah.

Terdiri dari 24 responden yang dibagi kedalam 2 kelompok yaitu :

12 responden pada kelompok intervensi. 12 responden pada kelompok control.

Populasi adalah klien stroke non-hemoragik.di unit Rehabilitasi Medik RS. Abd. Moeloek, Lampung. Sampel dalam penelitian ini adalah consecutive sampling, dimana semua subjek yang memenuhi kriteria inklusi dimasukkan dalam penelitian.

Besar sampel dalam penelitian adalah 20 responden.

Sampel dalam penelitian ini yaitu pasien stroke di Puskesmas Tanggu, Kabupaten Jember yang memenuhi kriteria inklusi yaitu sebanyak 30 responden. Makassar dengan jumlah 40 responden.
Sampel dalam pene- standar.

38 Klien diberikan perawatan standar plus mobilisasi dini setelah 24 jam serangan stroke akut sampa dengan 14 hari pertama.

Metode penelitian Penelitian ini bertujuan untuk yang digunakan mengetahui pengaruh dar adalah kuasi- penguatan kesehatan untuk eksperimental de- kemandirian klien pasca stroke ngan desain pre dan dalam melaksanakan kegiatan post test tanpa sehari-hari di rumah. kontrol.

Penelitian ini menggunakan desain quasy-experiment dengan menggunakan pendekatan "Non Equivalent Control Group" yang terdiri dari 2 kelompok yaitu kelompok perlakuan dan kelompok control. Penelitian dilakukan selama 2 minggu.

Penelitian ini menggunakan desain quasy-experiment (Pre dan Post Test Design) Penelitian dilakukan selama 28 hari.

Penelitian ini menggunakan metode eksperimental,

dengan desain two group - pre test \& post test.

15 responden dengan latihan aktif fleksi.

15 responden dengan latihan aktif ekstensi.

Uji yang digunakan adalah Uji ANOVA.

Penelitian dilakukan selama 8 minggu.

Penelitian ini menggunakan jenis penelitian Pre-Eksperimental dengan rancangan One Group Pre Test Post Test Design.
Tujuan penelitian adalah untuk melihat efektifitas kombinasi Rang of Motion (ROM) dengan kompres hangat terhadap peningkatan fleksibilitas sendi lutut.

Intervensi dilakukan selama 2 minggu :

Pada kelompok intervensi dilakukan $\left(60^{\circ} \mathrm{c}\right)$ dengan buli-buli selama 10 mnt.

Latihan dilakukan $2 \mathrm{x}$ sehari $8 \mathrm{x}$ gerakan.

Pada kelompok control hanya dilakukan latihan ROM saja dengan dengan frekuensi dan intensitas yang sama

Tujuan penelitian ini untuk mengetahui pengaruh Range $\mathrm{O}$ Motion (ROM) terhadap kekuatan otot dan rentang gerak pasien pasca perawatan stroke.

Intervensi dilakukan selama 28 hari Hari pertama akan dilakukan penilaian kekuatan otot responden (pre-Test), kemudian dilakukan latihan Range of Motion selama 28 hari.

Setelah 28 hari latihan ROM dilakukan penilaian kekuatan oto (Post-Test)

Tujuan penelitian untuk meliha pengaruh latihan Range of Motion (ROM) aktif terhadap perubahan rentang gerak sendi dengan menggunakan Goniometer yang bersertifikat ISOM (International Standards of Measurement)

Sebelum dilakukan latihan ROM dilakukan pengukuran rentang gerak sendi awal (pre-test).

Kemudian latihan ROM dilakukan selama 2 bulan.

Setelah penelitian, dilakukan pengukuran rentang gerak sebagai nilai akhir (post-test)

Tujuan penelitian yaitu untuk melihat pengaruh latihan Range of Motion (ROM) terhadap rentang gerak sendi ekstremitas atas pada klien pasca stroke dengan alat ukur Goniometer.

Sebelum diberikan latihan Range of latihan ROM dan kompres hangat pemulihan (SC, $\mathrm{P}=0.003$ ) dan VEM, $\mathrm{P}=0.001$ ) Hasil penelitian ini menyatakan bahwa mobilisasi dini pada pasien dalam waktu 24 jam dari munculnya stroke akut aman dan layak.

Skor rata-rata kemandirian klien pasca stroke dalam melakukan aktivitas sehari-hari di rumah sebelum diberi HLOC adalah 46,61 dengan standar deviasi 26,23 dan setelah HLOC meningkat menjadi 62,74 dengan standar deviasi 22,38

Hal ini menunjukkan bahwa perbedaan rata-rata skor indepedence dari pasien pasca stroke sebelum dan sesudah streghtening HLOC adalah 16,13 dengan standar deviasi adalah 10,54 , nilai $=8.517$ dan 0.0001 nilai probabilitas $\leq 0,05$.

Penelitian ini juga menyatakann bahwa pasien pada kategori usia dewasa (18 - 45 tahun) dan pra lansia (46 - 59 tahun) merespon dengan baik ketika diberi ROM dan motivasi mereka meningkat untuk melakukan aktifitas sehari-hari. Hasil penelitian dengan t-test independent diperoleh nilai $p$-value $=0,00$.

Dengan rata-rata peningkatan fleksibilitas :

Pada kelompok eksperimen :

Sendi lutut kanan : 9,58 $\pm 1,8810$

Sendi lutut Kiri : 9,58 $\pm 2,0210$

Pada kelompok control :

Sendi lutut Kanan : 3,83 $\pm 1,4030$

Sendi lutut kiri : $3,83 \pm 1,4670$

Dari penelitian yang telah dilakukan selama 28 hari diperoleh hasil bahwa terdapat selisih ratarata kekuatan otot hari 1 dan hari ke 28 adalah 0,45

Selisish nilai hari ke 1 dan hari ke 28 adalah 6,65

Hasil analisis bivariat didapatkan hasil uji statistik kekuatan otot menunjukkan nilai $\mathrm{t}=$ 3,943.

Hasil uji $p$-value $=0,001$

Hal ini berarti bahwa latihan ROM memiliki pengaruh terhadap kekuatan otot dimana terdapat perbedaan yang signifikan antara nilai kekuatan otot hari ke 1 dengan hari ke 28.

Hasil uji statistic kekuatan otot menunjukkan nilai $\mathrm{t}=-7.502$ deng $p$-value $=0,00$.

Hasil penelitian dengan uji ANOVA menunjukkan setelah dilakukan latihan ROM aktif terdapat peningkatan sudut atau perbaikan sudut rentang gerak fleksi sebesar $11,4^{0}$ dengan nilai $p$-value $=0,001(\mathrm{p}<0,05)$

Hal ini berarti ada perbedaan yang signifikan sudut rentang gerak fleksi sebelum dan sesudah latihan ROM aktif.

Terdapat penyempitan sudut atau perbaikan sudut rentang gerak ekstensi sebesar $19,80^{\circ}$ dengan nilai $p$-value $=0,001(\mathrm{p}<0,05)$.

Hal ini menunjukkan ada perbedaan yang signifikan sudut rentang gerak ekstensi antara sebelum dan sesudah latihan ROM aktif.

Hasil statistic dengan uji Wilcoxon didapatkan hasil Untuk gerakan fleksi pada sendi peluru, ekstensi sendi peluru, fleksi sendi engsel, ekstensi sendi engsel, fleksi sendi kondiloid, ekstensi sendi kondiloid diperoleh nilai p-value $=0,00$, dimana nilai $\alpha=0,05$.

Hal ini menunjukkan terdapat pengaruh latihan 
Author :

Pramono. C

Year :

2013

Author :

Gusti. R.P

Year :

2012

Author :

Rohimah. S

Year :

2014

Author :

Faridah. V. N.

Year :

2012
Jumlah populasi penelitian sebanyak 48 orang di RSUD. RM. Soedjarwadi, Jawa Tengah.

Teknik sampel penelitian menggunakan non-probability sampling dengan metode purposive sampling sebanyak 18 responden.

Kriteria Inklusi

(a) Lansia stroke yang berumur antara 60-74 tahun; (b) Lansia stroke dengan iskemia;

(c) Lansia stroke iskemia yang mengalami penurunan tingkat kemandirian activity daily living dengan tingkat ketergantungan sedang sampai berat.

Teknik pengambilan sampel yang digunakan dalam penelitian in adalah teknik purposive sampling

Subjek penelitian in pasien hemiparese pasca stroke iskemik dua kelompok yaitu kelompok pertama diberi latihan mobilisasi $2 \mathrm{x}$ /hari berjumlah 10 orang dan kelompok kedua $3 x / h a r i$ berjumlah 10 orang.

Responden berjulah 30 orang.

Tehnik pengambilan sampel adalah consecutive sampling didapatkan 20 sampel sesuai kriteria.

Jumlah sampel pada kelompok intervensi $=\mathrm{ROM}+\mathrm{SEFT} 10$ responden.

Kelompok intervensi II

= ROM tanpa SEFT 10

responden.

Sampel diambil dari pasien stroke iskemik menggunakan metode non probability sampling dengan teknik accidental sampling, berjumlah 32 pasien $\mathrm{d}$ RSUD. Soegiri Lamongan

Terdiri dari 16 responden pada kelompok perlakuan latihan ROM 3 x sehari.

16 responden kelompok kontrol latihan ROM 2 x sehari. Sampel adalah pasien
Uji yang digunakan adalah

Wilcoxon.

$\mathrm{Uji}$

Penelitian dilakukan selama 4 minggu.

Metode penelitian Quasy experiment dengan rancangan one group pretest and postest design dan menggunakan uji t-paired.

Sedangkan untuk pengukuran tingkat kemandirian activity daily living menggunakan skala NRS (Numeric Rating Scale)

Penelitian dilakukan selama 4 minggu.

Jenis penelitian adalah quasi eksperimen dengan rancangan two group pre test \& post test. Analisa menggunakan uji t berpasangan dan tidak berpasangan dengan derajat kemaknaan $\mathrm{p}$ < 0,05

Penelitian dilakukan selama 4 Bulan.

Penelitian menggunakan desain Quasi Experiment pre dan post test Control Group Desain.

Analisis statistik menggunakan uji sidik ragam (ANOVA) dengan signifikansi statistik ditentukan jika nilai $\mathrm{P}<0.05$.

Desain penellitian menggunakan

Quasy Eksperiment dengan pendekatan Non Equivalent Control Group

Uji yang digunakan adalah uji Wilcoxon.
Motion (ROM), dilakukan penilaian rentang gerak ekstremitas atas sebagai nilai Pre-Test.

Dan setelah dilakukan latihan ROM dilakukan lagi penilaian rentang gerak sebagai nilai Post-Test.

Penelitian ini bertujuan untuk mengetahui efektivitas latihan ROM terhadap peningkatan kemandirian activity daily living pada lansia stroke.

Sebelum Intervensi dilakukan penilaian tingkat kemandirian (Pre-

Test).

Kemudian diberikan latihan Range of Motion 2 x sehari selama 4 minggu.

Setelah intervensi diberikan, dilakukan penilaian akhir tingkat kemandirian sebagai nilai Post-Test

Tujuan penelitian untuk meliha efektivitas pemberian mobilisas dini terhadap kekuatan otot, tonus otot, kemampuan motorik fungsional pada hemiparese paska stroke iskemik di RSUP. Dr. M.Jamil Padang.

Kelompok pertama diberi latihan mobilisasi $2 \mathrm{x} /$ hari berjumlah 10 orang dan kelompok kedua $3 \mathrm{x} /$ har berjumlah 10 orang. mengidentifikasi efektikitas latihan ROM tanpa SEFT dan latihan ROM + SEFT terhadap kekuatan oto pasien hemiparese akibat stroke $\mathrm{d}$ RSUD. Tasikmalaya.

Penelitian ini bertujuan untuk mengetahui pengaruh frekuensi ROM terhadap peningkatan kemandirian fungsional pada pasien stroke.
Range of Motion (ROM) terhadap peningkatan rentang gerak sendi ekstremitas atas pada klien pasca stroke.

Hasil penelitian menunjukkan bahwa peningkatan kemandirian activity daily living pada lansia stroke rata-rata dari 5,89 menjadi 11,67 dengan St.Deviasi 1.132 dan hasil uji statistik dengan uji t-paired diperoleh hasil $\mathrm{p}=$ $0,000(\mathrm{p}<0,05)$
Hasil penelitian didapatkan adanya peningkatan pada kekuatan otot, kemampuan fungsional motorik pada kedua kelompok dengan masingmasing kelompok nilai $\mathrm{p}=0,000$.

Didapatkan peningkatan lebih baik pada kekuatan otot (bahu, siku, pergelangan tangan, paha, lutut, pergelangan kaki) dan kemampuan motorik fungsional kelompok yang mendapat terapi $3 \mathrm{x} /$ hari dari pada $2 \mathrm{x} /$ hari dengan nilai kemaknaan kekuatan otot pada bahu $\mathrm{p}=0,016$; otot siku dengan $\mathrm{p}=0,037$; otot pergelangan tangan $\mathrm{p}=0,042$;

otot lutut $\mathrm{p}=0,004$

pergelangan kaki $\mathrm{p}=0,050$.

Hasil penelitian menunjukkan kekuatan oto meningkat pada kedua kelompok intervensi dan terdapat perbedaan yang signifikan diantara kedua kelompok intervensi $(\mathrm{p}=0.018)$.

Hasilnya menunjukkan rata-rata kekuatan oto pada kelompok ROM sebelum dilakukan latihan adalah 1.93 dan sesudah dilakukan latihan adalah 3.13, (perubahan nilai sebesar 1.20).

Sementara itu rata-rata kekuatan otot pada kelompok ROM + SEFT sebelum dilakukan latihan adalah 2.07 dan sesudah dilakukan latihan adalahn 4.20, (perubahan nilai sebesar 2.13).
Hasil penelitian menunjukkan adanya peningkatan kemandirian baik dari kelompok kontrol maupun dari kelompok perlakuan.

Hasil uji statistik wilcoxon menggunakan tingkat kemaknaan $\mathrm{p} \leq 0,05$ menunjukkan hasi signifikan dengan nilai $\mathrm{p}=0,00$ untuk kelompok perlakuan dan $\mathrm{p}=0,00$ untuk kelompok kontrol. Kemudian untuk hasil uji mann whitney test tingkat kemaknaan $\mathrm{p} \leq 0,05$ untuk mengetahui perbedaan pengaruh frekuensi ROM 2x/hari dengan ROM 3x/hari menunjukkan nilai $\mathrm{p}=$ 0,00 . 
Vier Nofrel, Pengaruh Latihan Range Of Motion terhadap Peningkatan Kemampuan Melakukan Activity Daily Living pada Penderita Pasca Stroke

Mardati. L., et al

Year :

2014

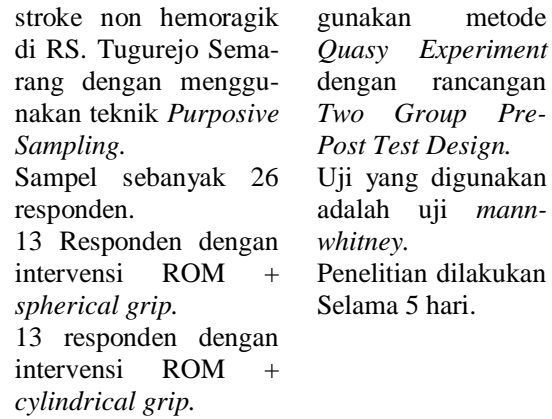

gunakan metode Quasy Experiment dengan rancangan Two Group PrePost Test Design.

Uji yang digunakan adalah uji mannwhitney.

Penelitian dilakukan Selama 5 hari.

\begin{abstract}
melihat perbedaan kekuatan otot ekstremitas atas pada pasien stroke. Sebelum dilakukan intervensi dilakukan penilaian kekuatan oto (Pre-Test) dan setelah intervensi 5 hari dilakukan lagi penilaian kekuatan otot (Post-Test). Kelompok pertama dilakukan intervensi berupa latihan ROM + spherical grip selama 5 hari. Kelompok kedua diberikan latihan $\mathrm{ROM}+$ cylindrical grip selama 5 hari.
\end{abstract}

peningkatan kekuatan otot dari sebelum dan sesudah diberikan intervensi spherical grip, dari 2,23 menjadi 3,15 .

Hasil penelitian menunjukkan terjadi rata-rata peningkatan kekuatan otot dari sebelum dan sesudah diberikan intervensi cylindrical grip, dari 1,92 menjadi 2,77.

Hasil uji statistik Mann Whitney menunjukkan $p$ value $=0,750(P>0,05)$, maka Ho diterima dan Ha ditolak.

\section{Pengaruh Range of Motion (ROM) terhadap Peningkatan Kemampuan Melakukan Activity Daily Living}

Aktivitas sehari-hari (Activity Daily Living atau selanjutnya disebut ADL) adalah aktivitas yang biasanya dilakukan dalam sepanjang hari normal; aktivitas tersebut menyangkut, ambulasi, makan, berpakaian, mandi, menyikat gigi, dan berhias (Potter \& Perry, 2005). Aktivitas didefinisikan sebagai suatu aksi energetika atau keadaan bergerak. Yang dimaksud dengan ADL adalah Kegiatan melakukan pekerjaan rutin sehari-hari (Hardywinoto, 2005).

Beberapa penelitian telah membuktikan tentang pengaruh latihan terhadap peningkatan kekuatan otot klien stroke. Penelitian yang dilakukan Smallfield.S at al (2009) tentang intervensi yang sering dilakukan dalam pemulihan klien pasca stroke menyatakan bahwa intervensi ROM masih sering digunakan dan dianggap efektif dalam meningkatkan tingkat kemandirian klien dalam melakukan aktifitas fisik, hal ini didukung oleh hasil penelitian yang dilakukan Hamzah dan Sugianto (2014) dimana terjadi pengaruh yang signifikan dari kemandirian klien pasca stroke dalam melaksanakan kegiatan sehari-hari dimana terjadi perbedaan nilai sebelum dan sesudah intervensi sebesar 16,13 dengan standar deviasi $10,54, \mathrm{p}=\leq 0,05$. Sedangkan penelitian yang dilakukan oleh Mayo.N.E, et al (2013) menyatakan terdapat peningkatan kemampuan klien dalam mempertahankan kapasitas berjalan setelah menjalani latihan selama 12 bulan dengan nilai $p=0,02$.

Penelitian lain yang dilakukan Murtaqib (2013), bahwa ada pengaruh yang signifikan antara sebelum dan sesudah latihan range of motion terhadap peningkatan kekuatan otot dan rentang gerak sendi siku pada pasien Stroke, dimana rata-rata rentang gerak sendi siku setelah dilakukan latihan ROM yaitu fleksi sebesar 136,67 derajat dan ekstensi sebesar 8,47 derajat. Hal tersebut sejalan dengan penelitian yang dilakukan Gusty (2012), yang juga menyatakan bahwa terdapat perbedaan kekuatan otot dan kemampuan motorik fungsional sebelum dan sesudah pemberian mobilisasi dini $2 x /$ hari pada pasien Stroke iskemik hemiparesis, dimana nilai kemaknaan kekuatan otot bahu $p=0,016$, otot siku $p=$ 0,037 , otot pergelangan tangan $p=0,042$, otot lutut $p=$ 0,004 dan otot pergelangan kaki $p=0,050$. Sedangkan penelitian yang dilakukan oleh Pramono (2013), menyatakan bahwa latihan ROM yang dilakukan selama 3 minggu pada pasien yang dirawat dirumah sakit efektif terhadap peningkatan kekuatan otot dan hal ini akan memberikan efek terhadap peningkatan kemandirian Activity Daily Living pada penderita Stroke dengan ratarata nilai Indeks Barthel dari 5,89 $\pm 1,132$ menjadi 11,67 $\pm 3,710$.

\section{SIMPULAN}

Dari beberapa hasil penelitian yang telah dilakukan oleh para peneliti dahulunya dapat disimpulkan bahwa latihan range of motion efektif dalam meningkatkan kemampuan rentang gerak klien guna menunjang dalam melakukan activity daily living. Latihan range of motion yang diberikan baik tanpa kombinasi metoda lain maupun dengan kombinasi metoda lainnya yang dilakukan dalam rentang waktu 2 minngu sampai dengan 3 bulan, memberikan efek positif terhadap klien pasca stroke yang mengalami gangguan mobilitas fisik dalam meningkatkan kemampuan rentang gerak klien guna menunjang dalam melakukan activity daily living.

Bagi peneliti selanjutnya diharapkan dapat melakukan penelitian lebih lanjut tentang perawatan pasien stroke terutama bagaimana peran keluarga sebagai caregiver yang memberikan perawatan langsung pada klien pasca stroke dirumah.

\section{DAFTAR PUSTAKA}

American Heart Association (2017). Let's Talk About Risk Factor For stroke. http://www.americanheart.org.

Bernhard, Julie et al (2017). A Very Early Rehabilitation Trial for Stroke (AVERT)Phase II Safety and Feasibility.

39(2):390-6. http://dx.doi.10.1161/STROKEAHA.107.49236 3. Epub.

Bustan, M.N. (2007). Epidemiologi Penyakit Tidak Menular, Cetakan 2. Jakarta : Rineka Cipta.

Faridah. V.N, (2012). Perbedaan Intensitas Range of Motion (ROM) Terhadap Peningkatan Kemandiriran Fungsional (ADL) Pasien Stroke Iskemik di Ruang Teratai RSUD. Soegiri Lamongan. Surya, Vol.01, No.XI, Aprl 2012. 
Vier Nofrel, Pengaruh Latihan Range Of Motion terhadap Peningkatan Kemampuan Melakukan Activity Daily Living pada Penderita Pasca Stroke

Fransiska, A., et. al. (2018). Pengaruh Latihan Range of Motion Terhadap Rentang Gerak Sendi Ekstremitas Atas Pada Pasien Pasca Stroke di Makassar. Journal of Islamic Nursing. 3(1), 2018. 97-106. e-ISSN : 2549-5127/p-ISSN : 2528-2549.

Gusty. R.P. (2012). Efektivitas Pemberian Mobilisasi Dini terhadap Tonus Otot, Kekuatan Otot, dan Kemampuan Motorik Fungsional Pasien Hemiparise Paska Stroke Iskemik. Jurnal Ners Keperawatan Vol. 8. 2012. (ISSN 1907-686X).

Hamzah, A., \& Sugiyanto (2014). Strengthening of Health Locus of Control could Increase the Independence of Post Stroke Patients in Implementing the Daily Activities at Home. J Nurs Care 3:152. doi:10.4172/21671168.1000152.

Handayani, S. (2014). Efektifitas Kombinasi Range of Motion (ROM) Dengan Kompres Hangat Untuk Meningkatkan Fleksibilitas Sendi Lutut Lanjut Usia. E-Journal. 9(19), 63-73.

Hsieh, Lin-Fen et al (2014).Combined Home Exercise Is More Effective Than Range-of-Motion Home Exercise in Patients with Ankylosing Spondylitis: A Randomized Controlled Trial. http://dx.doi.org/10.1155/2014/398190.

Lewis (2007). Medical Surgical Nursing. $7^{\text {th }}$ edition. St.Louis : Missouri. Mosby-Year Book, Inc.

Mardati, L., et. al. (2014). Perbedaan Range of Motion Spherical Grip dan Cylindrical Grip Terhadap Kekuatan Otot Ekstremitas Atasa Pada Pasien Stoke di RSUD. Tugurejo Semarang. E-Journal Stikes Telogorejo Semarang. 7(2), 1-10. ISSN : 2252-6854.

Mayo, N. E., MacKay-Lyons, M. J., Scott, S. C., Moriello, C., \& Brophy, J. (2013). A randomized trial of two home-based exercise programmes to improve functional walking post-stroke. Clinical Rehabilitation, 27(7), 659-671. doi: http://dx.doi.org/10.1177/0269215513476312.

Murtaqib (2013). Pengaruh Latihan Range of Motion (ROM) Aktif Terhadap Perubahan Rentang Gerak Sendi Pada Penderita Stroke. (The effect range of motion/ROM active on improvement of joint motion to stroke patients in Tanggul subdistrict Jember district). Jurnal IKESMA Volume 9 Nomor 2 September 2013. ISSN 18297773/ No Klas SER 614.05 IKE.

National Stroke Foundation. (2012). National stroke audit : Rehabilitation services report 2012. Melbourne, Australia; National Stroke Foundation Available. Diakses dari : http://strokefoundation.com.au/prevent-stroke/.

Pdpersi (2010). Stroke, penyebab utama kecacatan fisik. http:/pdpersi.co.id diakses tanggal 20 februari 2014.
Pinzon Rizaldy dan Laksmi A. (2010). Awas Stroke! Pengertian, gejala, tindakan, perawatan, dan pencegahan. Yogyakarta. ANDI.

Potter\& Perry. (2006). Fundamental Keperawatan : Konsep, Proses dan Praktik Edisi 4 vol 1. Jakarta: EGC.

Pramono. C. (2013). Efektifitas Latihan Range of Motion (ROM) Terhadap Peningkatan Kemandiriran Activity Daily Living (ADL) Pada Lansia Stroke. Journal of Nursing Science. Vol 7, No 1. 2013. ISSN: 2089-1466.

Riskesdas. (2018). Riset Kesehatan Dasar. Badan Penelitian dan Pengembangan Kesehatan Kementrian Kesehatan RI. Jakarta.

Rohimah. S, (2014). Efektikitas Latihan ROM Dengan Latihan ROM + SEFT Terhadap Keluatan Otot Pasien Stroke di RSUD Tasikmalaya (Effectivenes of Exercise Training With ROM + SEFT to Muscle Strenght of Stroke Patients in Hospital Tasikmalaya). Jurnal Kesehatan Bakti Tunas Husada Volume 12 No 1 Agustus 2014.

Smallfield, S., \& Karges, J. (2009). Classification of occupational therapy intervention for inpatient stroke rehabilitation. American Journal of Occupational Therapy, 63(4), 408-413.

WHO, (2010) New WHO Pocket-charts will save lives by predicting heart attack and stroke melalui http://www.who.int/mediacentre/news/release/.

WHO (2012). Cardiovascular Diseases, Available at : www.who.int/mediacentre/factsheets/fs317/en/pr int.html.

Yayasan Stroke Indonesia (2012). Tahun 2020 penderita stroke meningkat 2 kali. 2012.). Diakses dari: http://www.yastrokei.com/.

Yudha. F. \& Amatiria. G. (2014). Pengaruh Range of Motion (ROM) Terhadap Kekuatan Otot dan Rentang Gerak Pasien Pasca Perawatan Stroke. Jurnal Keperawatan, Volume X, No. 2, Oktober 2014. ISSN 1907-0357. 